University of Michigan Law School

University of Michigan Law School Scholarship Repository

Law \& Economics Working Papers

$12-1-2013$

\title{
Mandatory Rules and Default Rules in Insurance Contracts
}

\section{Tom Baker}

University of Pennsylvania Law School, tombaker@law.upenn.edu

Kyle D. Logue

University of Michigan Law School, klogue@umich.edu

Follow this and additional works at: https://repository.law.umich.edu/law_econ_current

Part of the Contracts Commons, and the Insurance Law Commons

\section{Working Paper Citation}

Baker, Tom and Logue, Kyle D., "Mandatory Rules and Default Rules in Insurance Contracts" (2013). Law \& Economics Working Papers. 86.

https://repository.law.umich.edu/law_econ_current/86

This Article is brought to you for free and open access by University of Michigan Law School Scholarship Repository. It has been accepted for inclusion in Law \& Economics Working Papers by an authorized administrator of University of Michigan Law School Scholarship Repository. For more information, please contact mlaw.repository@umich.edu. 


\title{
Mandatory Rules and Default Rules in Insurance Contracts
}

\author{
Tom Baker* and Kyle D. Logue ${ }^{* *}$
}

\author{
Draft \\ Forthcoming in The Law \& Economics of Insurance (Elgar Publishing)
}

\section{Introduction}

In the economic analysis of contracts, the rules of contract law divide into two general classes: default rules, which parties can contract around by agreement of the parties, and mandatory or immutable rules, which parties cannot alter. (Ayres \& Gertner, 1989; Barnett, 1992; Craswell 1999, Cohen 1999) According to this way of organizing the field, the essential normative issues similarly divide into two general questions: (a) what substantive contract law rules are most efficient; and (b) should those rules be mandatory or merely defaults. Insurance law raises these same questions. Although numerous scholars have examined the efficiency or inefficiency of particular substantive doctrines of insurance law, few scholars, and even fewer courts and policymakers, have considered whether and under what circumstances rules of insurance law should be default or mandatory. Nor have they seriously examined how state administrative regulation of insurance forms might affect the answers to these questions. This essay begins to fill these gaps in the literature.

Section II provides a brief summary of the law-and-economics of contract, with special emphasis on the theoretical justifications for making some rules of contract law, or some terms in contracts, mandatory. This section articulates a straightforward efficiency-based approach to drawing the line between which rules or terms should be mandatory and which should be changeable by agreement of the parties: that is, to draw the line in a way that is consistent with the market-failure rationale that justifies

\footnotetext{
${ }^{*}$ William Maul Measey Professor of Law and Health Sciences, University of Pennsylvania Law School.

${ }^{* *}$ Wade H. \& Dores M. McCree Collegiate Professor of Law, University of Michigan Law School.
} 
making contract rules mandatory or immutable in the first place. Section III describes how insurance law currently draws the line between mandatory rules and default rules, and Section IV evaluates whether those boundaries are consistent with the applicable market failure rationales. Section V takes into account the unique role that state insurance regulators can play in helping courts decide which rules of insurance law, or terms in insurance contracts, are mandatory and which are defaults. Section VI explains how the rules/standards distinction must be considered in the optimal drawing of the mandatory/default-rule boundary, and it suggests a "bright line" approach that draws the boundary on the basis of whether the policy is sold to a large commercial policyholder" (in which case default rules prevail) or to a consumer or a small commercial policyholder (in which case there will be some mandatory rules).

Relatively little has been written on the mandatory/default-rule boundary in the insurance law context. A number of articles have, in the context of evaluating particular insurance law doctrines, addressed whether the rule should be mandatory or waivable by agreement of the parties. For example, Seth Chandler discussed whether the duty to settle should be mandatory or waivable. (Chandler, 1993) Similarly, Erik Knutsen (Knutsen, 2010) argued in favor of a particular mandatory rule to address the problem of concurrent causation; and Michelle Boardman (2013) explored the mandatory/default-rule question in connection with contra proferentem. Kenneth Abraham (2001) noted that insurance law, in contrast with other areas of contract law, contains relatively few judicially created default rules, "because the insurance industry has already done so through the development of the standard-form policy provisions.” Those standard-form provisions, Abraham noted, serve the same function as majoritarian default rules. Abraham's conclusion is consistent with our approach. The question we raise, with respect to standard-form insurance policy terms, is whether those terms under certain conditions are (or should be) regarded as mandatory rather than merely as default. Abraham also pointed out a small number of judicially created mandatory insurance law rules, including the insurable interest requirement and the treatment of conflicting “other insurance” clauses, which we discuss below. None of these articles, however, addressed the general normative question of when insurance law doctrines (or terms in 
insurance law contracts) should be mandatory and when default, nor did they address how the mandatory/default line should be drawn.

\section{The Economic Analysis of Contract Law and the Mandatory/Default-Rule Boundary}

The economic analysis of law holds that the normative objective of contract law is to maximize efficiency. (R. Posner, 1986; Craswell, 1999; E. Posner 2002; Shavell, 2004) On this view, society allows contracting parties to use the judicial system to enforce their contractual promises precisely because doing so maximizes the joint utility of the contracting parties and thus of society generally. (Goetz \& Scott, 1983) Thus, contract law enables individuals and firms to bind themselves to an allocation of rights and responsibilities that makes both parties better off—or that at least makes one party better off without making the other worse off, which is the definition of Pareto efficiency. Assuming that the conditions of a competitive market are present (that is, the parties are reasonably well informed and suffer from no substantial cognitive biases, there is roughly symmetrical bargaining power, and there are no externalities), it follows almost tautologically that courts will maximize social utility if they enforce the explicit terms of the written agreement.

Written contracts, of course, whether by design or by accident, do not always fully specify the parties' intentions. Indeed, there is a sense in which contracts never cover every conceivable contingency; all contracts, in other words, are on some level incomplete, which is where default rules come in. Default rules "fill the gaps in incomplete contracts; they govern unless the parties contract around them.” (Ayres \& Gertner, 1989) As a result, a primary role for courts when applying contracts, for legislatures when enacting laws governing contractual relationships, as well as for scholars when writing about contract law is to identify the best default rules for various contractual situations. These will be the gap-filling rules that will apply where the parties fail to specify what they regard as the valuemaximizing outcome.

Identifying the most efficient contractual default rules in various settings has been the objective of a fair amount of economic contracts scholarship. One insight from this literature is that contractual 
default rules come in two general flavors. First, there are default rules designed to approximate what most parties would have agreed to, with respect to a particular contingency, under conditions of perfect information and zero transaction costs. Such "market-mimicking” or "majoritarian” default rules have the advantage of minimizing the need for contracting parties to incur the costs necessary to "contract around" the default rule. That is, majoritarian default rules can simply be used "off the shelf" and left in place by a majority of contracting parties; that is, they will need to be contracted around by only a minority of contracting parties, thus minimizing transaction costs. Some default rules, however, are not designed to minimize transaction costs, but instead actually are designed to induce parties to take action. Such rules, sometimes referred to as “information-forcing” or (the less appealing term) “penalty” defaults, are designed to disfavor the party with superior information in an attempt to induce that party either to negotiate for a more efficient allocation of rights and obligations or to change their primary conduct in some way. An example of such a rule would be the damages rule set forth in Hadley v. Baxendale, 9 Ex. 341 (1854). The Hadley rule says that only the damages typically recoverable in a contract case are those damages within the reasonable contemplation of the parties at the time the contract was entered into. Under the Hadley rule, if one party knows that it will suffer extraordinary damages in the event of a breach, it has an incentive to reveal that information in order to bring those damages within the contemplation of the party and thus within the scope of the contract.

As insurance law scholars have pointed out in prior work (E.g., Abraham, 1996; Abraham, 2001; Boardman, 2013), another contract doctrine that has penalty or information-forcing qualities is the interpretive doctrine of contra proferentem, which says that ambiguities in contractual language will be construed against the party who provided the language. That rule confronts contract drafters with the choice either to redraft the language of the contract to be clearer or to leave the language as it is and have the term construed against them. It should be noted, of course, that the doctrine of contra proferentem itself is not a penalty default rule. Contra proferentem is a contractual doctrine that acts as a tie breaker between two reasonable but incompatible interpretations of a contract term. In such a situation, the interpretation that favors the non-drafter is chosen as the meaning of the term. It is that tie-breaker 
interpretation of the contract term that is a penalty default, since the parties to the contract, or other parties to similarly worded contracts, can alter the wording of the term to have a different meaning going forward. Of course, contracting parties may elect not to contract around the court's tie-breaking interpretation of the contract term in question—for example, because redrafting the term may produce further ambiguity). (Boardman, 2006) But it is at least possible. By contrast, the doctrine of contra proferentem is best understood as either a majoritarian default rule (one that a majority of contracting parties would contract for) or a mandatory rule. On whether rules of contractual interpretation are, or should be, mandatory or defaults, see discussion in Section III and IV below.

As mentioned above, the choice of an efficient default rule is not the only normative question facing the economic analyst of contract law. A second, and in some situations more critical, question is whether a particular rule should be left as a default rule or whether instead should be made mandatory. ${ }^{1}$ From an economic perspective, a reasonable question to ask is why any rule of contract law would ever be compulsory? Why not always permit the parties to agree to terms that best suit their individual needs and preferences and thus maximize their own utility?

In the efficiency-oriented contracts literature, justifications for mandatory rules rely of course on claims of market failure. In particular making a rule of contract law mandatory can make sense if one of the parties lacks ready access to important information or is subject to cognitive biases that cause them to misprocess certain types of information. Similarly, if the contract produces external costs or benefits (costs or benefits experienced by parties who are not involved the contract and thus not able to represent their interests in the negotiations), the contracting process can produce inefficient outcomes. Finally, if one of the parties to the contract is in the position of a monopolist, and the other party has relatively few choices, it is sometimes argued that the terms of the contract can be inefficient, although economists often respond that even a monopolist will want to include all efficient contract terms (so as to produce more

\footnotetext{
${ }^{1}$ Of course, after a dispute has arisen between the parties, even a so-called mandatory term in the contract can be contracted around. (Ware, 1999).
} 
value to extort in the bargaining process). For a survey of these standard arguments, see Trebilcock (1993).

A number of existing mandatory contract law doctrines can be explained in terms of these market failures. One prominent example involves product liability law. During the last century, the law of product accidents has shifted from a regime in which responsibility for product-related personal injuries was governed purely by the terms of the contract between buyer and seller (a regime in which waivers of liability for personal injuries was enforced) to a regime in which responsibility for product-related injuries is governed by mandatory, non-waivable principles of tort law. The key point to recognize about this well-known and frequently discussed shift in products liability law is that it entailed both (a) a change in the underlying liability rule (the rule assigning responsibility for product-related injuries) ${ }^{2}$ and, more importantly for present purposes, (b) a change in the nature of the rule, from a default rule to a mandatory rule, as attempts to contract around it were deemed unconscionable. ${ }^{3}$

Both changes - the change in the liability rule and the change in nature of the rule from default to mandatory — have been justified on a number of different theoretical grounds. One of the most persuasive is a story of information asymmetry. Because product consumers as a group tend to be poorly informed about the risks posed by most consumer products relative to product sellers and because individual consumers tend systematically to underestimate the risks of product accidents (again, relative to product sellers), the market for consumer products cannot be expected, by itself, to produce optimally safe products and optimal consumer product warranties. That is, because of this information problem, we cannot expect consumer product contracts, including the warnings and disclosures made to consumers, to strike the optimal balance between product safety and product price. Consumers, being poorly informed and systematically underestimating risks of catastrophic losses that have very low probabilities, will be, contrary to their own best interests, unwilling to pay the cost for optimally safe products and for products that come with product-risk insurance. (Latin, 1994; Arlen 2010)

\footnotetext{
${ }^{2}$ Escola v. Coca Cola Bottling Co., 24 Cal. 2d 453 (1944); Greenman v. Yuba Power Products, Inc., 59 Cal. 2d 57 (1963); Restatement (Second) of Torts, § 402A (1965).

${ }^{3}$ Henningsen v. Bloomfield Motors, Inc., 161 A.2d 69 (N.J. 1960); U.C.C. §§ 2-715 \& 2-719.
} 
This story can be used not only to explain why it makes sense on efficiency grounds for legislatures or courts to adopt a liability rule that shifts product-injury costs to product sellers (who are, to use Calabresi's language, the cheapest cost avoiders), but also to justify making the strict liability rule mandatory or nonwaivable by the parties to the contract. If the rule of strict products liability could be altered simply by the insertion of a product warranty waiver, such waivers would inefficiently proliferate, eliminating the effect of the rule. Consumer products that did not include the waiver, that leave the strict liability rule in place, would be more expensive than the consumer products that waived the rule; and, because consumers are unaware of or underestimate the risks of product-related injuries, they would not be willing to pay the additional cost, which their better informed or less cognitively biased selves would be willing to pay.

Thus, in the product liability example, both the choice of the particular liability rule and the choice to make the rule nonwaivable can be, and should be, grounded on the same market failure rationale-here the problem of information asymmetry. (Croley \& Hanson, 1993) This point applies to all default rules in contract law: whatever the theoretical justification for the choice of the rule, the choice whether to treat the rule as mandatory or waivable in a particular case should be consistent with that theoretical justification. As a corollary to this principle, the nature of the market failure that justifies the underlying rule also bears on whether a rule should be mandatory or default for all parties and in all circumstances, or only some. Thus, insofar as the mandatory nature of modern products liability law is based on the presumption that consumers tend to underestimate product risks, the rules of products liability law should be mandatory only in circumstances in which this information problem exists.

The rules regarding the products liability mandatory/default boundary in most states are roughly consistent with this approach. For example, the Uniform Commercial Code permits disclaimers for consequential damages, but only if they are not unconscionable; and the doctrine of unconscionability itself is likely to take into account the information asymmetry problem that exists between product consumers and product sellers. Moreover, the U.C.C. presumes that such a disclaimer is unconscionable in the case of personal injuries involving “consumer goods.” (U.C.C. § 2-719(3)) 
Note that the same basic point could be made if the market-failure rationale for the liability rule is something other than information asymmetry. Thus, if the argument in favor of the underlying legal rule is based on some sort of externality story or a bargaining power asymmetry, then the choice of the mandatory/default-rule boundary should track that story as well.

\section{Mapping the Mandatory/Default-Rule Boundary in Insurance Law}

As with contract law generally, the overwhelming majority of the law that governs the parties' actions is found in the language of the contracts themselves. Although the vast majority of insurance policies are standard form contracts, which policyholders (rationally) never bother to read until a loss occurs, there are good reasons why the rights and responsibilities of insurers and insures are governed primarily by the plain language of the policies. (ALI 2013) Therefore, because the language of insurance contracts can be altered by insurers (or by the insurance trade associations) that draft the policy language, there is an important sense in which the law governing insurance arrangements consists primarily of default rules or default contract terms. .

There are, however, ways in which the parties to insurance contracts are not free to choose whatever outcome they wish. The common law of insurance or a particular state's insurance code (or the regulations promulgated by the insurance regulatory authority under the authority of that state's insurance code) may impose limitations on what terms may be inserted into an insurance policy, how those terms will be interpreted by courts, or what background duties will be imposed on insurers and insureds. This section divides such mandatory rules into three general categories: (1) insurance policy terms that are expressly required by state legislatures or by state insurance regulators to be included into certain types of insurance policies; (2) basic contract and insurance law duties; (3) the rules of contract interpretation and enforcement. This section also discusses one large potential loophole in all of these mandatory rules: arbitration clauses. Later in this essay we will revisit these mandatory rules in light of the role of state administrative agencies in deciding whether to approve standard form insurance policies drafted by or on behalf of insurance companies. This approval process means that a rule that is a default rule under the 
common law of insurance may become an immutable rule when the state insurance department refuses to approve any insurance policy that attempts to contract around that rule. Prior literature has largely ignored this possibility and the additional options it opens up for the common law of insurance. We will do so for the moment as well.

1. Insurance policy terms expressly required by statute or regulation. It is well known that insurance contracts are regulated in a way that most other contracts are not. The aspect of this regulation that prior literature has emphasized is mandatory insurance contract terms. State regulation of the insurance industry traces back to the 1940s, when the McCarran-Ferguson Act, among other changes, created what might be called the reverse preemption presumption: the rule that, unless Congress clearly says otherwise, no federal law will be construed to preempt state regulation of insurance, including the regulation of insurance contracts. Since that time, all 51 jurisdictions in the US have adopted comprehensive insurance regulatory regimes. Although the primary focus of state insurance regulation has historically been the solvency of insurance companies, states also sometimes mandate that particular terms be included in certain types of insurance policies. When such laws or regulations exist, the required terms are by definition mandatory rules.

Perhaps the most famous example of mandated insurance is the Affordable Care Act's (ACA's) requirement that all individuals purchase health insurance- the so-called individual mandate. For the purposes of our analysis, however, the important part of the mandate is not the requirement that coverage be purchased, but the mandatory terms in the policies themselves. With respect to individual and smallgroup policies sold after the 2010 grandfather date, the ACA requires certain “essential health benefits,” which include ambulatory patient services, emergency services, hospitalization, maternity and newborn care, mental health and substance use disorder services, and prescription drugs. (42 U.S.C. § 18022(b).) ${ }^{4}$ Similar mandatory terms in health insurance policies have existed for years in some states. Perhaps the more pervasive state-level insurance mandates, however, appear in the area of auto insurance. Every jurisdiction in the country requires the purchase of some amount of auto liability insurance coverage.

\footnotetext{
${ }^{4}$ The minimum essential group benefits that large employers must provide under the ACA are less clear.
} 
Many states also statutorily limit auto insurers' ability to cancel or rescind policies to situations in which premiums have not been paid or the insured's driver's license has been suspended or revoked. (See, e.g., Miss. Code Ann. § 83-11-3.) Similarly, with respect to uninsured and underinsured motorist coverage, state statutes forbid insurers from using policy terms that are less favorable to insureds than the statutorily prescribed coverage. See, e.g., Steffen v. Progressive Northern Ins. Co., 276 Neb. 378 (2008) (construing the uninsured motorist law to forbid the insurer from defining an exclusion more broadly than contemplated by the statute).

Over the years, states have begun to require specific terms in many different policies. For example, some states now require insurers to insert in all of their policies a term explicitly excluding coverage for losses caused “willfully” or “intentionally” by the insured. (See, e.g., Cal. Ins. Code § 533.) A somewhat controversial example of a mandatory insurance contract term involves the issue of multiple concurrent causes. (Knutsen, 2010) Insurance companies sometimes wish to exclude particular causes, either for moral hazard reasons (as with the intentional harm exclusion already mentioned), for market segmentation reasons (a particular risk is better insured through a different type of policy), or for other reasons (perhaps the risk in question is entirely uninsurable). The interesting question is what should be done when a given loss has more than one cause, one that is covered and one that is specifically excluded. Some insurers have drafted and redrafted their policies to make clear that coverage is not owed if an excluded cause- - earth movement or flood, for example- has any causal connection whatsoever to the loss, no matter how remote. Some states have applied such language literally in favor of insurers. In other states, however, legislatures have been unwilling to permit insurers to draft such exclusions and have instead enacted laws requiring that causal exclusions apply only if the excluded cause was the “dominant” or "primary” or "efficient proximate” cause of the loss in question. Examples include California (Cal. Ins. Code § 530) and North Dakota (N.D.C.C. §§26.1-32-01). In those states, the dominant cause requirement has in effect been made a mandatory term in every insurance policy. In other states, the efficient proximate cause rule is merely a default rule, which insurers have successfully 
contracted around. (Assurance Co. of Am., Inc. v. Jay-Mar, Inc., 38 F.Supp.2d 349, 353-54 (D. N.J. 1999).)

There are many other examples of statutorily mandated insurance contract terms. In the context of occupational disability coverage, for example, California (which has more than its share of mandatory rules) has defined "total disability" to be the insured's inability to perform the substantial and material duties of her own occupation, even if the policy contains language expressly conditioning such coverage on not being “engaged in any other gainful occupation.” (Hangartner v. Provident Life and Acc. Ins. Co., 373 F.3d 998 (9th Cir. 2004)).

2. Common law duties. Certain duties developed in the common law of contracts can also be understood as mandatory terms in every insurance policy. For example, it is hornbook law that every contract, including every insurance contract, contains an implied duty on the part of all parties to the contract to act in good faith, or to refrain from acting in bad faith, when enforcing their contractual rights and or carrying out their contractual obligations. (See, e.g., U.C.C. § 1-102(3) (stating that the obligation of contracting parties to act in good faith may not be disclaimed by agreement of the parties.)) This general duty has been interpreted to have a number of implications in the insurance context. One example involves the insurer's duty to pay benefits owed. In most if not all jurisdictions, an insurer who relies on a patently unreasonable interpretation of the language in the policy to refuse payment to a deserving insured may later be found by a court to have breached the duty of good faith and fair dealing. (Barker 2012) Such a breach can expose the insurer to not only compensatory consequential damages but also punitive damages. And the duty to act in good faith is mandatory. A term in an insurance policy purporting to eliminate the duty of good faith and fair dealing would almost certainly be struck down as unenforceable. As a result, every insurance policy contains this implicit, nonwaivable contractual term.

The duty to defend and the duty to settle in liability insurance policies are examples of what might be called quasi-mandatory implied contract terms. They are "quasi” rather than fully mandatory because, although insurers can eliminate the duties contractually, they can do so only by redrafting their 
policies in ways that substantially alter the allocation of rights and responsibilities between the insurer and insured. Take the duty to defend. If a liability insurance policy includes a term giving the insurer the right, and imposing on the insurer the obligation, to "defend the insured against any suit seeking damages” (as most liability insurance policies do), the meaning of that duty will be shaped by the judicial doctrine that has developed interpreting that language. Thus, for example, courts have generally interpreted the duty to defend to be broader than the duty to indemnify. This means, among other things, that if a complaint filed against an insured contains even a single allegation that if proven would be covered, the insurer must provide the insured with a defense, even if that allegation later turns out to be false or fraudulent. This "complaint-allegation rule" is the prevailing law in most jurisdictions. (ALI, 2013)

What's more, it seems likely that such a rule would be applied to any liability policy that imposes on the insurer the obligation to defend the claim (and by defend the claim we mean actually provide the defense—choose the lawyer, supervise the litigation, etc., and not merely indemnify the insured's defense costs), even if the insurer attempted to contract around it. Put differently, while a liability insurer can contract out of this duty by eliminating the duty to provide a defense (by, for example, making clear that it only pays for indemnification costs after the liability has been resolved, and not for ongoing defense costs), if the insurance contract contains a term stating that the insurer will provide or pay for the defense, that term will necessarily be interpreted in light of the judicial doctrine that has developed in this area. The American Law Institute’s Principles of Liability Insurance Law (PLLI) treats these rules as mandatory for all so-called "duty to defend" policies—-that is, policies that impose on the insurer the obligation actually to handle the defense of the case, and not merely to reimburse defense costs. (ALI 2013) “Defense cost indemnification policies," however, are treated differently under the PLLI. If a the defense cost indemnification policy obligates the insurer to pay the costs of defense on an ongoing basis, then the rules developed in the duty to defend context apply on a mandatory basis for defense cost indemnification policies other than those issued to large commercial policyholders. If, however, the 
policy obligates the insurer simply to reimburse the costs of defense after the claim has been resolved, the PLLI does not impose the usual duty to defend style rules.

The duty to settle is similarly a quasi-mandatory rule. Most liability insurance policies contain a provision giving the insurer the discretion to settle any claim brought against the insured. This allocation of authority makes sense, given that the insurer, which is defending the suit, will have better access to information necessary to make a reasonable settlement decision and given that, in many cases, it is mostly the insurer's money that is on the hook. However, in situations in which there is a possibility of a judgment in excess of the policy limits, the insurer will sometimes have an incentive to reject reasonable settlement demands in favor of litigating the case, because it will be risking not only its own money but also the insured's money. Given this conflict of interest, courts have created an implied duty on the part of liability insurers that sell such policies to make reasonable settlement decisions—defined as decisions that a reasonable party facing the entire liability would make. Although insurers could eliminate that duty by redrafting their policies to remove the insurer's discretion to settle (and thus the conflict-of-interest created by the excess judgment scenario), it seems unlikely that a court would enforce a term that maintained the insurer's settlement discretion but eliminated the insurer's duty to make reasonable settlement decisions. This conclusion is supported by the fact that the duty to settle developed out of the duty of good faith, which, as we have already noted, is generally not waivable.

3. Rules of contract interpretation and enforcement. The basic rules of interpretation developed in the common law of contract are generally considered mandatory, and this is true in the insurance context as well. (Rappaport, 1995; Boardman, 2013) For example, the doctrine of contra proferentem, under which ambiguous terms are construed against the party who supplied the term, is routinely applied in insurance cases (typically to the benefit of insureds against insurers), irrespective of whether there is language in the policy seeking to eliminate that rule. However, it is difficult to find examples of cases in the U.S. in which this proposition has ever been tested. While there are a few reported cases of policies with such provisions, in none of those cases is the provision tested because the 
insurance policy term at issue was jointly drafted by the parties. ${ }^{5}$ Insurance policies in the U.S. rarely contain such provisions. Indeed, we have not been able to find a single example of a standard form insurance policy issued in the United States that contains a term seeking to eliminate or otherwise alter the traditional contra proferentem rule, either because insurance regulators will not permit such terms or because the parties believe such terms will be held unenforceable in court (or perhaps because the parties are happy with the existing rules of interpretation). There are, however, insurance policies written in other countries, between insurers and very sophisticated commercial policyholders, that include provisions purporting to eliminate or alter contra proferentem. For example, the "Bermuda Form,” developed for use in the large commercial liability insurance market based, contains an arbitration clause as well as a clause that specifically contracts around the contra proferentem rule. (Jacobs, Masters \& Stanley, 2004).

In addition to the rules of contract interpretation, there are the rules of contract enforcement, all of which tend to be mandatory, making these rules in effect mandatory implicit terms in every insurance contract. In some jurisdictions, for example, courts have held that a policy purporting to cover intentionally caused losses is unenforceable on public policy grounds, on the theory that permitting such insurance would increase incentives for insureds to cause losses intentionally, the classic moral hazard concern. (E.g., K2 Investment Group, LLC v. American Guarantee \& Liability Ins. Co., 2013 WL 2475869 (NY Ct. Ap. 2013) Likewise, the insurable interest requirement says that, if (or to the extent that) an insured has no insurable interest in the thing being insured against (that is, she stands to lose nothing if the insured event happens), the insurance policy in question will typically be found unenforceable, again on moral hazard/public policy grounds. The same can be said of the doctrine of unconscionability, or the related, and sometimes indistinguishable, insurance law doctrine of reasonable expectations. If there is a term in a standard form insurance policy that results in the insured losing coverage and that seems patently unfair (that is, it is difficult to imagine that an informed party with any sort of bargaining options would have knowingly agreed to the term in question), or the term is wildly out

\footnotetext{
${ }^{5}$ See, e.g., I.U. N. Am., Inc. v. A.I.U. Ins. Co., 896 A.2d 880, 884-85 (Del. Super. 2006)
} 
of sync with what a reasonable person would expect to find in such a contract, some courts have been known to treat such terms as unenforceable. (See, e.g., C\&J Fertilizer v. Allied Mutual Ins. Col., 227 N.W.2d 169 (Iowa, 1975)) In addition, courts have used the doctrine of “disproportionate forfeiture” to justify similar decisions, to avoid enforcing policy terms that would, if read literally, cause an insured to lose coverage for what seems like a minor breach of a technical requirement in the policy. For example, in situations in which a policyholder fails to satisfy a clearly written notice requirement in an insurance policy, most courts will nevertheless hold in favor of the insured, because the insurer failed to show “substantial prejudice” from the delay. (E.g., Aetna Casualty \& Surety Co. v. Murphy, 538 A.2d 219 (Conn, 1988)) Whether imposed statutorily or judicially, such prejudice requirements amount to mandatory contract terms.

4. Potential loophole to mandatory rules. All three of the above-listed categories of mandatory insurance law rules are subject to one large potential loophole: the mandatory binding arbitration clause. If an insurance policy contains a mandatory arbitration provision, and if there is no state statute or insurance agency regulation that specifically says mandatory arbitration clauses are unenforceable, such a clause may well be enforced by the courts. Once an insurance despite is in arbitration, there is no guarantee that the arbitrators will apply the rules of insurance law that are traditionally considered mandatory by the courts. Arbitration clauses often contain choice-of-law provisions, which can be used by the parties to apply the laws of a jurisdiction that has fewer mandates. For example, Bermuda-form policies often provide that the insurance laws of New York will apply, but that interpretive rules such as contra proferentem will not. (Abraham \& Montgomery, 2003)The Bermuda-Form policy, of course, is a negotiated contract. Whether mandatory arbitration clauses in standard form contracts are enforceable, even in situations in which they run afoul of some state-law contract doctrine (such as prohibitions on unconscionable terms), has become a matter of some controversy. The trend in the federal courts, especially the Supreme Court, has been to enforce arbitration clauses in such contexts, based on an expansive, and thus state-law preempting, interpretation of the Federal Arbitration Act (FAA). The most prominent case is AT\&T Mobility v. Concepcion, 
decided in 2011. That case involved a mandatory arbitration provision in a standard-form mobile phone contract eliminating any right to bring class action lawsuits or arbitration actions against a wireless provider. The Supreme Court held that applying the state's unconscionability law to strike down the mandatory arbitration provision in that contract would violate the FAA.

There is an important difference, however, between the context of standard-form consumer contracts generally (including standard form mobile phone contracts) and the context of insurance contracts. As mentioned above, the insurance industry in general is much more heavily regulated than most industries, and standard form insurance contracts in particular are much more heavily regulated than most standard form contracts. One example of this difference is the regulation of mandatory arbitration clauses, which have been banned from insurance contracts in a number of states. More specifically, there are at least twelve states with statutes expressly forbidding arbitration clauses in insurance contracts sold in those states. In at least five states, although there are no insurance statutes directly on point, there are regulatory pronouncements from the insurance regulators forbidding arbitration terms in particular types of insurance policies. (Kravec, 2012) In addition there are likely to be even more state insurance departments that would refuse to approve insurance policy forms that contained an arbitration clause. (This latter possibility grows out of the same regulatory authority that we will consider below.)

The next question is whether such state-law prohibitions on arbitration clauses in insurance contracts would be enforced, despite the recently expanded interpretations of the Federal Arbitration Act. Although the Supreme Court has not ruled on the subject, it seems likely that the McCarran-Ferguson Act, and the reverse preemption presumption discussed above, will be found to trump the FAA, since the FAA nowhere specifically states that it was meant to preempt state insurance law or apply to the "business of insurance.” Indeed, some lower courts have so held. ${ }^{6}$

\section{Evaluating the Mandatory/Default-Rule Boundary in Insurance Law}

\footnotetext{
${ }^{6}$ See, e.g., State of Wash. Dep't of Transp. v. James River Ins. Co., 176 Wash.2d 390 (2013) (en banc); Mutual Reinsurance Bureau v. Great Plains Mutual Insurance Co. 969 F.2d 931, 934 (10th Cir. 1992).
} 
There are two steps in the normative economic analysis of a rule of contract law. First, what rule efficiently allocates rights and responsibilities as between the contracting parties? Second, should that rule be a mandatory rule or merely a default rule? We have emphasized that the two questions are closely connected with each other; the same arguments that justify the choice of the efficient rule of contract law also have implications for the decision regarding whether and to what extent the rule should be mandatory. Thus, for example, if a rule is justified on grounds of information asymmetry, the mandatory/default-rule boundary should also track that information asymmetry. By contrast, if the rule is not a response to concerns about information asymmetry but rather is designed to protect third parties who may be harmed by the transaction or to overcome bargaining-power asymmetries, the mandatory/default boundary should track that rationale: where the externality exists, the rule should be mandatory.

Some aspects of the mandatory/default boundary in insurance law are consistent with this efficiency story; others are not. The doctrines of unconscionability, reasonable expectations, and disproportionate forfeiture all are typically justified on information or bargaining-power rationales; and the mandatory/default boundary seems roughly consistent with those rationales as well. A contract term will be held unconscionable and therefore unenforceable only under conditions in which there is likely to be information and/or bargaining-power asymmetries—situations involving standard form boilerplate terms in policies sold to consumers. And courts typically apply doctrines such as reasonable expectations and disproportionate forfeiture only in situations which the contracts are standard form policies drafted by insurers and where no negotiation of terms takes place, which correlates to some extent with when the insured is commercially sophisticated. (Stempel, 1993; Beh, 2004).

Mandatory auto insurance presents an especially interesting case. State auto insurance statutes typically require only that the auto owner maintain a certain level of liability insurance. The primary justification given for these requirements is the desire to protect innocent third party victims of auto accidents. Such laws were first enacted at a time when auto-related injuries and deaths were on the rise and when first-party health and disability insurance markets were not well developed. In addition, state 
auto-liability insurance requirements responded to the problem of judgment proof drivers: drivers who have insufficient assets to cover the losses their driving might cause to others. In the absence of such mandates, auto owners have an incentive to carry insufficient insurance to cover the losses their driving might cause. Therefore, compulsory auto insurance is primarily a response to an externality problem. This is presumably why, in some states, car owners can get out of the requirement of buying an auto insurance policy if they can prove that they otherwise are "financially responsible" - that is, have sufficient assets to pay for any harms their driving causes. However, car owners are not permitted to avoid the auto liability insurance requirement simply by demonstrating that they are highly sophisticated or well informed about the risks. Again, this difference demonstrates the basic point: the line between mandatory and non-mandatory insurance law rules should be defined in ways that are consistent with the market failure rationales that justify the rules in the first place.

Not all auto insurance mandates are necessarily in response to externality concerns. For example, mandatory health insurance terms are meant to protect the insureds themselves from the possibility of certain types of health-care expenses. But why should such terms be mandatory? Shouldn’t consumers be permitted to decide for themselves whether such coverage is worth the price? The argument to the contrary must be that individual consumers do not fully understand the risks of debilitating auto injuries, and thus will underestimate the value of such coverage in the market. It is also possible, however, to make externality-type adverse selection arguments: in the absence of the mandate, relatively low risk individuals will tend to opt out of the insurance regime, causing premiums to rise for everyone else.

The externality argument is clearest for rules that prohibit contract terms that threaten harm to third parties. If insurance companies could contractually agree to provide coverage in situations in which the insured has no insurable interest, for example, the risk of moral hazard would obviously increase. Insureds would have an incentive to take out policies on property that they do not own, for which they are not a lessee or have any other economic interest (or, in the worst case scenario, to take out coverage on the life of someone unrelated to them), and then to destroy the property (or the person) in order to recover the insurance. While there are clear criminal laws that punish this sort of behavior, there is nothing 
wrong, from an efficiency perspective, with adding the additional discouragement of refusing to enforce the policy terms. Similar arguments could apply to the public policy doctrine that forbids insurance against intentional harms, at least in the first party insurance context. In the liability insurance context there are competing externalities - moral hazard and victim compensation. The better approach in the liability insurance context is to address the moral hazard concern by permitting the insurer to subrogate against the insured or by reducing the amount of the insurance in cases when insureds have the capacity to pay (thereby promoting the victim compensation externality). In any event, the mandatory nature of externality-based rules should, and apparently does, extend to all insureds and not just those that are poorly informed, as all insureds (if the well informed) would be subject to the moral hazard problem.

Here we should emphasize the difference between two types of mandatory insurance law terms: those that tend to favor a finding of coverage (such as insurers' implied duties to defend and to settle) and those terms that tend to favor a finding of no coverage (such as the public policy doctrine as applied to intentional harms). The pro-coverage mandatory terms will obviously tend to produce higher premiums, assuming the additional coverage is non-trivial in magnitude. These mandatory terms are analogous to the mandatory product-risk insurance implied by the modern products liability, as discussed above (which also results in higher product prices). The anti-coverage mandatory terms, by contrast, tend to lower premiums overall, compared with insurance policies that do not have the terms. The mandatory nature of both of these types of mandatory terms, however, make sense from an efficiency perspective: that is, in both situations, the contracts that would be produced by the market, if these terms were alterable by agreement of the parties, would likely be inefficient.

One especially interesting set of (mostly) mandatory rules in insurance law are such basic contract doctrines as contra proferentem, waiver and estoppel, misrepresentation, and the general duty of good faith and fair dealing. As mentioned, American contract law seems to treat these rules as being largely mandatory, except insofar as state regulators permit insurance contracts to include mandatory arbitration clauses (and even then, it isn't clear to what extent arbitration does away with such doctrines). Although articulating the full efficiency justification for each of these doctrines is far beyond the scope of 
this essay, such a justification is not difficult to imagine. Indeed, such justifications have become a part of the standard economic analysis of contract law. As an efficiency matter, should parties to insurance contracts be permitted to contract around these rules? In our view, the answer to that question is highly dependent on the particular doctrine at issue and on the specific facts on the ground. For example, we doubt that it makes sense to permit standard form insurance policies to include terms that waive the doctrine of contra proferentem (and we doubt that most insurance regulators would permit such a term), because the beneficial incentive and risk-allocative effects of the doctrine would seem to be useful for all types of insureds, sophisticated or not, and for all types of policies. (Indeed, if a contract contains a term that truly cannot be given a single reasonable meaning, what rule could be more efficient than imposing the cost on the party responsible for supplying the term?) The same may not be true, however, with other basic contract doctrines, especially the ones whose function is to protect only the least sophisticated insureds. With such doctrines, it might make sense to permit the most sophisticated insurance purchasers, who do not need the protection of a rule, to opt out of it. We talk further about this possibility in Section VI below.

Does the quasi-mandatory nature of the duty to defend and the duty to settle make sense from an efficiency perspective? Should liability insurers, for example, be able to alter the standard defense obligation to provide that, defense costs paid by the insurer must be reimbursed by the insured if the claim being litigated is ultimately determined not to be covered under the policy—which is not permitted under the standard duty to defend? Certainly in the context of policies sold to unsophisticated parties, when individuals purchase insurance that purports to cover defense costs as well as damage and settlement payments within the policy limits, it seems likely that the expectation is that duty to defend will be broader than the duty to indemnify; and being required, after the fact to reimburse the costs of the defense would come as a shock. Thus, just as warranty disclaimers for personal injuries in product liability cases are unenforced, perhaps the same argument would apply to justify requiring duty to defend policies not to require reimbursement. 
But on this argument, why then would we permit liability policies that do not provide for coverage of defense costs at all? Wouldn't individual insureds expect to be receiving a defense with their liability policy, even if the policy clearly provides otherwise, given that such coverage has historically been provided with liability insurance? We think that extending the mandate to require that liability insurers provide defense cost coverage would be going too far. It is our view that consumers would easily be able to understand the distinction between liability policies that cover defense costs and those that do not, in part because such a distinction would correlate with substantial differences in premiums, whereas fine-tuning the defense mandate would easily go unnoticed, or not fully understood, given the relatively minimal effect on premiums. ${ }^{7}$ A similar story could be told with respect to the duty to settle.

Given the importance of the mandatory/default-rule issue, it is interesting that courts deciding insurance law cases so rarely, in fact almost never, address the question explicitly. This probably has to do with the fact that some insurance policy terms are simply required by law (see examples above) and it may also relate to the fact that insurance policies generally must be approved by a regulatory agency before they are used by insurers (see the next section); therefore, courts in insurance cases may feel especially inhibited from ruling on the mandatory/default-rule issue. Another reason that courts do not address the mandatory/default-rule question directly is that the issue is so rarely presented. Most impliedin-law insurance contract terms are true gap fillers, in the sense that courts create the terms in circumstances in which the insurance contract is silent or ambiguous with regard to some issue that is critical to the question of coverage in the particular case. In that context, there is just no need for the court to address the counter-factual question whether an unambiguous term to the contrary would be enforceable.

A final reason that courts rarely address directly the mandatory/default-rule question in insurance law may be that the judges realize that they probably are not in the best position to make the decision in most cases. Consider the amount of information a court would need to have to make such a ruling, if it

\footnotetext{
${ }^{7}$ Whether it would make sense for the insurer to offer to consumers or small businesses a liability insurance policy without defense coverage is a different question - one that insurance law leaves to the insurance market to work out.
} 
were going to do so in a way that is consistent with the efficiency framework outlined here. Again, the question whether the rule should be mandatory or default turns on not only whether there is a market failure present but also what the nature and extent of the market failure is. This is not a type of analysis for which a court is ideally suited. This may explain why most mandatory terms in insurance contracts result from legislation or regulatory intervention, rather than judicial decision. Whereas courts are considered the best fact finders with respect to what happened in a particular case, legislatures and administrative agencies are generally thought to be better fact-finders with respect to questions of general market failures and determining when and what sort of government intervention is called for. Such "polycentric" inquiries are inherently legislative or regulatory in nature. This is of course not to say that courts should never take on a regulatory role. Recall the example of products liability law, where it was the courts that pioneered certain interventions in consumer product markets, including both the adoption of the strict products liability rule and the decision to make that rule mandatory and non-waivable by contract. Such judicial interventions can be appropriate and useful. But they are and should be relatively rare, and they should be carefully tailored, especially in areas in which the legislature and the regulatory authority are active, as exemplified by the number of Supreme Court preemption cases addressing the appropriate role of products liability law in the regulation of pharmaceutical products given the presence of Congressional and administrative agency regulation of that market. The following section addresses more specifically the role of state insurance regulators in drawing the mandatory/default-rule boundary.

\section{Considering Administrative Review of Insurance Forms}

The analysis of standard form contracts in the insurance setting is different from the analysis of standard form contracts in other settings, in at least one important way: The terms used in insurance contracts are subject to the approval of a public regulator, the state department of insurance. This fact, which has gone largely ignored in the insurance contract law literature, has important implications for insurance law. Given that the insurance regulator is in the best position to determine whether and to what extent a market failure exists with respect to a particular type of insurance or in a particular insurance 
market, it should matter to the mandatory/default-rule question whether the regulator has approved or declined to approve a particular term. But just how should it matter? This section addresses that question.

The regulation of insurance forms is one of the core functions of state insurance departments throughout the United States. State regulation of forms differs along such dimensions as (1) whether an insurer must obtain active approval of the department before using a form or whether the insurer may use the form as long as the department does not refuse to approve the form within a certain period (recognizing that, as applied, this could be a distinction without a difference), (2) whether there are exemptions from the approval/non-disapproval requirement, for example for the very large commercial market, and (3) the amount of staff time and other resources devoted to the substantive review of insurance policy forms. However, insurance departments in all states have at least the formal legal authority to refuse to approve an insurance policy form on the grounds that, in the judgment of the insurance department, the form is not in the public interest. Insurance departments' formal legal discretion in this regard is very broad, making the department's decision the last word on whether a form may be used in the state or not. ${ }^{8}$

1. When the insurance regulator rejects a particular policy term.

Taking this regulatory oversight of insurance contract terms into account, consider the effect on the mandatory/default-rule boundary when an insurance regulator refuses to approve a policy term. Imagine, in particular, the case of an insurer that wants to alter a recent pro-coverage judicial interpretation of an existing term in the insurer's insurance policy. With that in mind, the insurer submits a revised version of the policy for approval by the regulator, a version that contains new language that makes explicit that there should be no coverage in the situation in which the court said that there was coverage. In such a case, if the regulator says no, then the old term-as well as the pro-coverage judicial

\footnotetext{
8 “The decision to approve, disapprove, or withdraw an insurance policy form is within the sound discretion of the Insurance Commissioner. (citing M.C.L.A. § 500.2236 and Rory v. Continental Ins. Co., 473 Mich. 457, 703 N.W.2d 23 (2005).” 119 A.L.R. 877 (Originally published in 1939).
} 
interpretation of that term-is now clearly mandatory. It may have been mandatory before; but the regulator has removed any doubt about the question.

How likely is this to happen? The insurance contract law literature typically assumes that insurers can get whatever forms they want through the state administrative agency. Yet, insurance companies frequently complain that state insurance departments will not approve their forms. Moreover there is circumstantial evidence that insurance departments do exercise their authority to refuse to approve insurance policy forms that would contract around implied-in-law terms. The evidence comes in two forms. The first is the surprising dearth of authority regarding the mandatory (or not) nature of a variety of insurance law rules that are widely disliked within the insurance industry, such as contra proferentem, the use of extrinsic evidence to interpret insurance policy terms, and the complaint allegation rule approach to determining when a liability insurer has the duty to defend a claim. If insurers could get insurance departments to approve whatever terms they wanted, some would have obtained approval of forms that tried to contract around these rules, and those forms and the judicial reaction to them would have left traces among the hundreds of thousands of recorded insurance decisions. Moreover, at least some insurers do try to contract around these rules in other jurisdictions, as demonstrated by the Bermuda form of liability insurance, which contains an interpretation provision that declares both contra proferentem and extrinsic evidence out of bounds. (Masters et al)

The second piece of evidence that insurance regulators do not always accept whatever policy change that insurers request is the otherwise surprising absence of state-specific variations in insurance policy forms that attempt to contract around the results of pro-policyholder court decisions regarding insurance law issues on which state law is split. For example, perhaps the relative dearth of instances in which insurers attempt to contract around contra proferentem holdings that go against them and in favor of coverage are the result either of regulators refusing to approve of policy revisions that would alter the outcomes of those decisions or insurers deciding not even to attempt such policy revisions on the belief that such policyholder-unfriendly changes would be rejected by the regulators. The other reasons that insurers do not attempt more often to contract around contra proferetem rulings have been emphasized in 
Michelle Boardman's work on the persistence of ambiguous boilerplate in insurance policies. (Boardman, 2006) Boardman argues that insurers may choose not to redraft their forms, even though the court would permit them to do so, because they have decided that they can live with the court's implied-in-law term and, perhaps, because they can take advantage of the ambiguity in their dealings with insureds. We think the regulatory oversight (or fear of regulatory oversight) explanation is just as important in understanding why there are not more cases asking courts consider whether their earlier implied-in-law creations are mandatory.

Another example relates to liability insurers’ right to recoup their defense and settlement costs when they defend and settle a claim for which they subsequently prove that they had no duty to defend. The court decisions that refuse to permit insurers to recoup those costs point to the fact that the insurance policy does not contain a term authorizing such recoupment. Some decisions even state that they would reach a different result if there were such a provision in the policy. Yet, neither commercial general liability insurance policies nor the liability coverage part of personal liability policies are offered in forms that explicitly permit recoupment. While there are state-specific endorsements to these forms, such endorsements appear to consist entirely of terms that are mandated by state legislation or regulation, not terms that contract around state-specific default rules.

At this point, we have no way of estimating how frequently insurance departments (or insurers acting strategically in relation to insurance departments) turn a default, gap-filing implied-in-law term into a mandatory insurance contract term. But our sense is that the frequency is well above de minimis, especially if we include in that category decisions by insurers not to redraft that are based on the judgment that there is a risk that the redrafted form will not be approved. If we are right, the regulation of policy forms by state insurance regulators may not be the rubber stamp that the insurance contract law literature assumes it to be.

\section{When the insurance regulator approves a particular policy term.}

While it seems clear that the explicit regulatory disapproval of a change to a policy term (or of a change in the interpretation of the policy term), in effect, makes that term (or interpretation of the term) 
mandatory, the effect of a regulator's approval of a particular policy term proposed by an insurer is less clear. As courts have pointed out before, regulatory approval of a policy term does not resolve the question of interpretation; thus, even if a policy term has been approved for use in a policy, whether the term is ambiguous is a question that only the courts can resolve as they are the ones who actually apply the contract term in question to particular situations.

The more interesting question, and one that has been largely ignored in the literature, is whether a court is obligated to enforce a term in a standard form policy that is indisputably unambiguous and that was approved by the regulator for use in the policy. An argument can be made that such an unambiguous term ought to be enforced by the courts, so long as the regulator is (a) acting within its statutorily granted authority and (b) demonstrably carrying out its role as protector of policyholder interests. Although a full articulation of this argument is beyond the scope of this essay, to the extent that it is persuasive, there is an important corollary that is relevant to the current discussion: regulatory approval of a standard form term should generally trump any otherwise mandatory judicial doctrine or implied-in-law term that contradicts it.

The anti-concurrent cause exclusion found in many modern property insurance policies provides an example. The vast majority of courts have been willing to enforce those exclusions when the exclusions unambiguously result in a denial of coverage in particular concurrent-cause situation, even when those jurisdictions had an implied-in-law (dominant or proximate cause) rule that goes the other way. Thus, the implied-in-law term was a default rule. This outcome is, in our view, justifiable at least in part because of the fact that a regulator approved the exclusion. If there were no such regulatory approval, as in most non-insurance contractual settings, the court would be required to do its own independent enforceability analysis, deploying such doctrines as unconscionability and reasonable expectations. $^{9}$

\footnotetext{
${ }^{9}$ The decision by the California courts not to enforce the clear anti-concurrent-cause exclusions is an exception that proves the rule. However, the California court's decision was based largely on a statutory provision. Specifically, an insurer in California is by statute liable for a loss "of which a peril insured against was the proximate cause, although a peril not contemplated by the contract may have been a remote cause of the loss; but he is not liable for a
} 
On the most extreme version of this view, if a term is approved by the regulator, the court should not have the authority to find the term unenforceable, unless the court can make the case that the agency has somehow exceeded or failed to exercise its oversight authority or, perhaps, that a particular application of the term raises public policy concerns that were not considered by the agency. (A narrower formulation of the latter exception would limit it to public policy concerns that a reasonable agency would not have foreseen.) Unless one of these exceptions applied, a court would have to enforce the term even if it thought that the term was ill-conceived or the product of some sort of market failure.

The reason for such a decision rule has to do with comparative institutional advantage. As discussed above, insurance regulators are usually in a better position than courts to make determinations about the presence or absence of market failures in insurance markets and the implications of those market failures for what terms should be mandatory or default. More generally, insurance regulators should be in a better position than courts to determine what is in the best interests of insurance purchasers - what the average insurance buyer expects to get when they buy coverage and how much they expect to pay for it. If it is true that state insurance regulators have a comparative advantage over courts (because of their information-gathering abilities and their expertise in insurance markets), then a decision by a regulator that the overall social benefits of a particular policy term outweigh the costs should not be overridden by a court.

That conclusion assumes, of course, that the insurance regulator is not exceeding its authority granted by the legislature and that the regulator is in fact doing its job. Informed decisions by active, engaged state insurance departments have much to commend them. And insurance regulators, as mentioned, are not always the rubber stamps that some scholars suggest. But they are almost certainly not always a model of regulatory efficiency and thoroughness either. Whether, when, and how much

loss of which the peril insured against was only a remote cause.” Cal. Ins. Code $\S 530$. This statutory definition was then held to supersede a conflicting definition that was in the insurance policy, and that was obviously approved by the state insurance regulator. See Howell v. State Farm Fire \& Cas. Co., 218 Cal.App.3d 1446 (1990) (disapproved of on other grounds in Reid v. Google, Inc., 50 Cal.4th 512 (2010)). In a sense, then, it was the California legislature, rather than the California court, that made the determination that the dominant cause rule would be mandatory rather than default. As a result, it was the state legislature and not the court that was overriding the regulatory decision to approve the term. 
courts should defer to a state insurance department's approval of a form are big questions, too big for this essay. But we can at least outline a few factors that a court might take into account in deciding how much to defer and under what circumstances.

Obvious factors to consider would include the need for insurance-specific expertise and agencystyle fact-finding authority to make a good decision about the enforceability of an insurance policy term, the presence of the relevant expertise and fact-finding authority in the particular insurance department that approved the term at issue, and the quality of the insurance-policy review process that was in place for the term being litigated. ${ }^{10}$ Courts that seriously consider these factors and give strong deference when appropriate, and little or no deference when not, could help improve the efficiency of the insurance market by encouraging insurance departments to invest additional resources in the policy review process. The argument here is analogous to an argument sometimes made in connection with judicial deference to federal agency decision making. That is, some commentators have suggested that the decision by courts to defer to federal agency interpretations of statutes should depend to some extent on whether the agency is applying is special expertise in a genuine effort to carry out congressional purposes. (Eskridge \& Baer, 2008).

\section{Rules Versus Standards in the Drawing the Mandatory/Default-Rule Boundary}

The distinction between rules and standards in law is familiar, and the economic analysis of this distinction is well known. Rules require the lawmaker to have a great deal of information ex ante, before

\footnotetext{
${ }^{10}$ Two kinds of rules for which insurance regulators have less expertise than courts and, thus, for which significantly less deference by courts may be due are (a) rules that are merely the insurance-specific instantiation of ordinary contract law rules, such as interpretation, waiver and estoppel, misrepresentation, the duty of good faith, and remedies, and (b) rules that relate to the involvement of insurance in the civil justice system. Courts, judges in particular, have substantial relevant expertise regarding both sets of rules, especially the first. With regard to the second, courts are most likely to have insurance-specific expertise in the context of liability actions, and they are more likely than insurance departments to prioritize access to civil justice. Thus, to the extent insurance law rules should take into account such civil justice externalities as victim compensation and civil recourse, courts have greater institutional competence, since courts decide not only insurance contract cases but also tort cases. This obviously is a concern only with respect to insurance law doctrines as they are applied to liability insurance, where there are injured victims who (a) are not a party to the insurance contract, and thus will not necessarily be well protected by the terms of the agreement between insurer and insured, and (b) are not an active and engaged constituency of the insurance regulator, and thus will not necessarily be well protected by the decisions of the agency.
} 
the regulated event takes place. Standards are relatively vague and open-ended by comparison, and their efficiency depends on the ability of the legal decision maker, often a court, to provide those standards with content in the application to particular cases after the regulated event takes place. For example, whereas choosing the optimal speed limit (the quintessential rule) can be difficult and in some ways arbitrary, applying that rule to particular cases is relatively simple. One is either speeding or not. By contrast, a standard that prohibits "reckless driving” must be given content by the courts applying the standard to particular cases. The economic analysis of rules and standards reaches an unsurprising conclusion: sometimes rules are more efficient; sometimes standards are; and sometimes it is efficient to have both.

How does the rule/standard distinction apply to the mandatory/default-rule question in contract law and insurance law? As it turns out, there is an approach to drawing the mandatory/default-rule boundary that is more standards-based and there is an approach that is more rules-based. Which approach is more efficient will depend on the situation. To see this basic point, consider an example of a rulesbased approach adopted in the recently approved first chapter of the American Law Institute’s Principles of the Law of Liability Insurance (PLLI), of which we are the reporters. The PLLI recommends a new rule designed to protect a particular class of insureds who are likely to be relatively unsophisticated in commercial matters. The rule itself has to do with the insurer's defense of misrepresentation. The traditional rule is that an insurer may defend against a claim for payment under a policy, and may retroactively rescind that policy, if it can show that the insured made a material misrepresentation on which it (the insurer) reasonably relied. And the rule, as stated in the hornbooks and as applied in most jurisdictions, had something of a strict liability flavor to it. That is, the insurer is not required to show any sort of fault on the part of the insured. This rule has proven to be disastrous for insureds who make innocent misstatements on their insurance applications that turn out to be material. The new PLLI rule provides protection for innocent insureds, by limiting the insurers’ rescission remedy to situations in which they can demonstrate that the misrepresentation by the insured was either intentional or reckless. 
The rule is meant to protect the relatively unsophisticated insured. However, the relevant question for current purposes is whether this new rule should be mandatory or waivable by contract.

In answering this question one could imagine either a standards-based approach or a rules-based approach. A standards-based approach might permit insurance contracts to waive this new protection for the insured if and only if the court enforcing the contract were to determine that the insured in the case were sufficiently commercially sophisticated and to be able to protect itself in the negotiation process. Under such an approach, courts hearing insurance contract disputes would be called on to assess the relative sophistication of the insureds. The benefit of this approach would be its flexibility: only the parties in need of protection would receive it, at least insofar as the courts do a good job of drawing the distinction between commercially sophisticated and commercially unsophisticated parties. The downside of such a standards-based approach, however, is apparent: Not only would it be difficult for courts to determine commercial sophistication in particular cases, the fact that such a determination would have to be made in each case would itself create uncertainty for insurers. They would have to guess what rules would apply to their contracts-whether particular waivers of the new misrepresentation protection would be enforced—in deciding what premiums to charge.

The rules-based approach, a version of which the PLLI adopted, is much simpler and entails less uncertainty. Under such an approach, the class of parties who would be entitled to contract around the new misrepresentation protection would be defined ex ante (as with the speed limit). Thus, the PLLI provides specifically that the new protection for unintentional and non-reckless misrepresentations should be merely a default rule for "large commercial policyholders" but should be mandatory for everyone else. Further, the PLLI defines a large commercial policyholder in a very specific way, tying the definition to a particular net-asset threshold that is used in federal securities laws (which is presently $\$ 10$ million). The idea behind this particular way of drawing the mandatory/default-rule boundary is that (a) consumer insureds will be mandatorily protected, (b) small business insureds will also be mandatorily protected, but (c) larger business insureds would be able to contract out of the new remedy if they so chose. The obvious downside of the rule is that it is both over-inclusive and under-inclusive. On the over-inclusive 
side, some consumer and small business insureds are in fact commercially sophisticated and can probably take care of themselves; if they choose to waive the new misrepresentation protection, then it is probably the efficient outcome. But the PLLI's rule-based approach does not permit them to do that. On the under-inclusive side, some business insureds with more than $\$ 10$ million in net assets may well be relatively unsophisticated when it comes to purchasing insurance, but they are not protected by the PLLI's rule; if their policies contain a waiver of the new protection, the PLLI say that such a waiver should be enforced. Our view is that the costs of this rule-based approach are exceeded by the benefits. Which is to say that they are exceeded by the costs of the alternative, standards-based approach, described above.

\section{Conclusion}

Designing an efficient regime of insurance law, as with contract law generally, requires not only efficient default rules and mandatory rules, but must also have a sensible way of determining when a rule will be one or the other. Most insurance policies are standard form agreements whose language is crafted by insurance companies and their representatives, and the terms of those policies can be altered by the drafters, within the limits of what state regulators will allow. Although most of insurance law, therefore, is determined by the agreement of the parties, some terms in policies are made mandatory by legislation or by regulatory fiat; and some insurance law doctrines impost mandatory obligations on the parties. This essay has provided a typology of mandatory insurance law rules and argued that those rules should be made mandatory only when there is a market failure rationale for doing so. In addition, the essay explains the role, and the potential role, of the insurance regulator in determining whether a particular rule of insurance law is mandatory or merely a default. For example, some terms are probably included in insurance policies by insurers, and some terms are probably excluded, because of the belief that the regulator would otherwise not permit the policy to be sold. This is a form of implicit regulatory mandate for those terms. Finally, the essay explains how the rules/standard distinction can play role in the optimal mandatory/default-rule boundary. 


\section{References}

Abraham, Kenneth S. 1996. “A Theory of Insurance Policy Interpretation.” 95 Michigan Law Review 531-69.

Abraham, Kenneth S. 2001. "Peril and Fortuity in Property and Liability Insurance.” 36 Tort \& Insurance Law Journal 777-802.

Abraham, Kenneth S. and J. W. Montgomery, III. 2003. "The Lawlessness of Arbitration.” 9 Connecticut Insurance Law Journal 355-69.

Arlen, Jennifer (2010), “Contracting over Malpractice Liability”, 158 University of Pennsylvania Law Review 957-1023.

Ayres, Ian \& Robert Gertner. 1989. “Filling Gaps in Incomplete Contracts: An Economic Theory of Default Rules,” 99 Yale Law Journal 87-130.

Barker, William. 2012. New Appleman Insurance Bad Faith Litigation. Lexis-Nexis.

Barnett, Randy E. 1992. “The Sound of Silence: Default Rules and Contractual Consent,” 78 Virginia Law Review 821-911.

Beh, Hazel Glenn. 2004. “Reassessing the Sophisticated Insured Exception.” 39 Tort Trial \& Insurance Practice Law Journal 85-120.

Boardman, Michelle E. 2006. “Contra Proferentem: The Allure of Ambiguous Boilerplate.” 104 Michigan Law Review 1105-28.

Boardman, Michelle E. 2013. “Penalty Default Rules in Insurance Law.” 40 Florida State University Law Review 305-48.

Chandler, Seth J. 1993. “Reconsidering the Duty to Settle.” 42 Drake Law Review 741-806.

Cohen, George M. 1999. “Implied Terms and Interpretation in Contract Law,” in Bouckaert, Boudewijn and De Geest, Gerrit, eds., 3 Encyclopedia of Law and Economics, Volume III: The Regulation of Contracts. Cheltenham: Edward Elgar. 
Craswell, Richard. 1999. “Contract Law: General Theories,” in Bouckaert, Boudewijn and De Geest, Gerrit, eds., 3 Encyclopedia of Law and Economics, Volume III: The Regulation of Contracts. Cheltenham: Edward Elgar.

Croley, Steven P. \& Jon D. Hanson. 1993. "Rescuing the Revolution: The Revived Case for Enterprise Liability.” 91 Michigan Law Review 863-797.

Eskridge, William N., Jr. \& Lauren E. Baer. 2008. “The Continuum of Deference: Supreme Court Treatment of Agency Statutory Interpretations from Chevron to Hamdan.” 96 Georgetown Law Review 1083-1226.

Goetz, Charles J. \& Robert E. Scott. 1983. “The Mitigation Principle: Toward a General Theory of Contractual Obligation.” 69 Virginia Law Review 967-1024.

Jacobs, Richard, Lorelie S. Masters \& Paul Stanley. 2004. Liability Insurance in International Arbitration: The Bermuda Form. [Press]

Knutsen, Erik K. 2010. “Confusion about Causation in Insurance: Solutions for Catastrophic Losses,” 61 Alabama Law Review 957-1023.

Latin, Howard. 1994. “’Good’ Warnings, Bad Products, and Cognitive Limitations.” 41 UCLA Law Review 1193-1295.

Posner, Eric. 2002. “Economic Analysis of Contract Law after Three Decades: Success or Failure?” 112 Yale Law Journal 829-80.

Posner, Richard. 1986. Economic Analysis of Law. Boston \& Toronto: Little Brown ( $3^{\text {rd }}$ ed.)

Rappaport, Michael B. 1995. “The Ambiguity Rule and Insurance Law: Why Insurance Contracts Should Not Be Construed Against the Drafter.” 30 Georgia Law Review 171-257.

Shavell, Steven. 2004. Foundations of Economic Analysis of Law. Cambridge, Massachusetts \& London, England: Harvard University Press.

Stempel, Jeffrey W. 1993. “Reassessing the 'Sophisticated Policyholder’ Defense in Insurance Coverage Litigation.” 42 Drake Law Review 807-58. 
Trebilcock, Michael J. 1993. The Limits of Freedom of Contract. Cambridge, Massachusetts \& London, England: Harvard University Press.

Ware, Stephen J. 1999. “Default Rules from Mandatory Rules: Privatizing Law Through Arbitration.” 83 Minnesota Law Review 703-54. 